genes conferring resistance to trimethoprim may occur more rapidly and in preference to the development of chromosomal resistance.

The overall prevalence of sulphonamide resistance in clinical isolates of enterobacteria means that a large proportion of the isolates must have been resistant to sulphonamides before exposure to trimethoprim. Furthermore, the fact that the proportion of trimethoprim $\mathrm{R}$ plasmids also carrying sulphonamide resistance had risen in 1979 to $63.4 \%$ (table III) - that is, $22.0 \%$ of total trimethoprim-resistant isolates-means that in an increasing proportion of isolates resistance to trimethoprim and sulphamethoxazole could have developed simultaneously, and no protective effect could therefore be exerted by the sulphonamide.

Another worrying feature was the increase in resistant isolates that failed to transfer their high-level trimethoprim resistance of $\geqslant 1024 \mathrm{mg} / 1\left(22.9^{\circ} \%\right.$ in 1979 compared with $4.7 \%$ in 1978). This may have been due to the spread of plasmids not capable of transferring to the standard $E$ coli recipient strain used. Alternatively it may have resulted from the transposition of genes conferring trimethoprim resistance from plasmids to the bacterial chromosome. The plasmids isolated in London that belonged to the $M$ incompatibility group carry the $\operatorname{Tn} 7$ transposon determining trimethoprim and streptomycin resistance. ${ }^{11}$ This DNA sequence may transfer with great efficiency between plasmids and the bacterial chromosome. ${ }^{13}$ Transposons of this type also occur in plasmids from strains of $E$ coli isolated outside hospitals from epidemiologically unrelated environments. ${ }^{14}$ In our surveys $13\left(54 \cdot 2^{\circ}\right)$ out of 24 plasmids isolated in 1978 and $31(75.6 \%)$ out of 41 isolated in 1979 (table III) conferred linked resistance to trimethoprim and streptomycin. These results support the possibility that spread of the $\operatorname{Tn} 7$ transposon is occurring and suggest a reason for the increase in isolates resistant to high levels of trimethoprim that failed to transfer their resistance. Further work to examine this hypothesis is in progress.

\section{References}

1 Jobanputra RS, Datta N. Trimethoprim R factors. in enterobacteria from clinical specimens. F Med Microbiol 1974;7:169-77.

${ }^{2}$ Maskell R, Okubadejo OA, Payne RH, Pead L. Human infections with thymine-requiring bacteria. $\mathcal{F}$ Med Microbiol 1977;11:33-45.

${ }^{3}$ Brumfitt W, Hamilton-Miller JMT, Grey D. Trimethoprim-resistant coliforms. Lancet 1977 ;ii :926.

4 Towner KJ, Pearson NJ, Cattell WR, O'Grady F. Chromosomal resistance to trimethoprim. Lancet $1978 ; \mathrm{i}: 1371$.

5 Brumfitt W, Franklin I, Hayek LJ, Leigh DA, Pursell R, Tsekos GR. A comparative study of the treatment of urinary infection in domiciliary practice with ampicillin, cephalexin, co-trimoxazole and trimethoprim. In: Brumfitt W, Asscher AW, eds. Urinary tract infection. London: Oxford University Press, 1973:229-39.

${ }^{6}$ Anderson JD, Lacey RW, Lewis EL, Sellin MA. Failure to demonstrate an advantage in combining sulphamethoxazole with trimethoprim in an experimental model of urinary tract infection. $\mathcal{F}$ Clin Pathol $1974 ; 27$ : 619-22.

7 Kasanen A, Anttila M, Elfving R, et al. Trimethoprim. Ann Clin Res 1978;10,suppl 22:1-39.

8 Towner KJ, Pearson NJ, Cattell WR, O'Grady F. Trimethoprim R plasmids isolated during long-term treatment of urinary tract infection with co-trimoxazole. $\mathcal{F}$ Antimicrob Chemother 1979;5:45-52.

9 Amyes SGB, Emmerson AM, Smith JT. R factor mediated trimethoprim resistance: result of two three-month clinical surveys. $f$ Clin Pathol $1978 ; 31: 850-4$.

${ }^{10}$ Towner KJ. Classification of transferable plasmids conferring resistance to trimethoprim isolated in Great Britain. FEMS Microbiology Letters $1979 ; 5: 319-21$.

11 Datta N, Hughes VM, Nugent ME, Richards H. Plasmids and transposons and their stability and mutability in bacteria isolated during an outbreak of hospital infection. Plasmid $1979 ; 2: 182-96$.

12 Grüneberg RN. Susceptibility of urinary pathogens to various antimicrobial substances: a four-year study. F Clin Pathol 1976;29:292-5.

13 Barth PT, Datta N, Hedges RW, Grinter NJ. Transposition of a deoxyribonucleic acid sequence encoding trimethoprim and streptomycin resistances from R483 to other replicons. F Bacteriol 1976;125:800-10.

${ }^{14}$ Barth PT, Datta N. Two naturally occurring transposons indistinguishable from Tn7. 7 Gen Microbiol 1977;102:129-34.

(Accepted 29 November 1979)

\title{
Controlled trial of supervised exercise training in chronic bronchitis
}

\author{
D J M SINCLAIR, C G INGRAM
}

\section{Summary and conclusions}

In a controlled trial of exercise retraining in patients with severe chronic bronchitis, 33 subjects were followed for a mean period of $10 \cdot 3$ months. The exercise programme was supervised once a week, and daily training comprised a 12-minute walk and simple stair climbing exercises. The subjects in the exercise group showed a highly significant improvement in their walking distance, attaining a maximum increase of $24 \%$ after eight to 12 months. There was also considerable subjective improvement. The control group did not improve. No significant changes in cardiorespiratory function or muscle strength were seen.

Simple exercise rehabilitation is of benefit to patients with disabling obstructive lung disease.

Department of Clinical Measurement, Ninewells Hospital and Medical School, Dundee DD3 8EA

D J M SINCLAIR, $M B, M R C P$, senior registrar in respiratory diseases

C G INGRAM, MB, DA, senior lecturer in physiology

\section{Introduction}

Using simple unsupervised exercise, McGavin et al showed small but statistically significant improvements in the 12minute walking distance in patients with severe chronic bronchitis. ${ }^{1}$ We report here the results of a training programme which was carefully supervised in the hope of producing greater improvement in the exercise capacity of such patients.

\section{Patients and methods}

Thirty-three patients were studied. All had been heavy cigarette smokers and had symptoms of chronic bronchitis in accordance with the Medical Research Council definition. ${ }^{2}$ Patients with symptomatic ischaemic heart disease, hypertension, peripheral vascular disease, and neurological or musculoskeletal problems were excluded. When they had recovered from the acute exacerbation those in hospital started daily 12 -minute walking distance assessments ${ }^{3}$ while the others were admitted to familiarise them with the exercise regimen. Immediately before discharge, when they were considered to be in an optimal condition clinically, pulmonary function and exercise capacity were assessed.

Forced expiratory volume in one second $\left(\mathrm{FEV}_{1}\right)$ and forced vital 
capacity (FVC) were measured on a dry wedge spirometer; total lung capacity, functional residual capacity, and residual volume were measured by closed circuit helium dilution; and the single breath carbon monoxide transfer factor was estimated. The 12-minute walking distance was assessed on a level corridor. As all the patients had previous experience of this test only a single measurement was necessary. ${ }^{34}$ Exercise capacity was also measured by a progressive submaximal exercise test on an electrically braked cycle ergometer. Isometric quadriceps muscle strength was assessed for each leg using a strain gauge ${ }^{5}$ and mid-thigh circumference measured. All subjects had a chest radiograph and 12-lead electrocardiogram.

To facilitate follow-up those patients who lived within the city were enrolled in the exercise group and those who lived outside the city to the control group.

In hospital a daily 12-minute walking distance test and stair climbing exercise were supervised by a research nurse. Stair climbing comprised stepping up and down on two $24-\mathrm{cm}$ steps for $1 \frac{1}{2}-2$ minutes twice daily according to the individual's ability. The subjects in the exercise group continued these exercises at home and were seen for weekly follow-up by the nurse, who supervised a full training programme. The exercise schedule was increased when possible, and each patient recorded his daily exercise on a diary card. After any relapse of their bronchitis training was restarted when the patient was considered fit. The exercise group were also reviewed and reassessed by a doctor every two months.

The control group did not continue with daily exercise after discharge and were not reviewed by the nurse. Both groups were advised to discontinue smoking and as far as possible drug treatment was not changed. All patients were reviewed and reassessed fully after six months, and most attended a final assessment, either 10 or 12 months after discharge from hospital.

Results were analysed using a paired-sample Student's $t$ test.

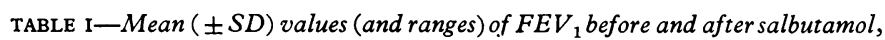
FVC, and 12-minute walking distanci cn entry to the trial for exercise and control groups

\begin{tabular}{lcc}
\hline & $\begin{array}{c}\text { Exercise group } \\
(\mathrm{n}=17)\end{array}$ & $\begin{array}{c}\text { Control group } \\
(\mathrm{n}=16)\end{array}$ \\
\hline Age (years) & $65 \cdot 6 \pm 8 \cdot 5(50-83)$ & $64 \cdot 0 \pm 7 \cdot 3(46-78)$ \\
FEV $(1)$ & $1 \cdot 10 \pm 0 \cdot 48(0 \cdot 40-1 \cdot 85)$ & $1 \cdot 02 \pm 0 \cdot 57(0 \cdot 55-2 \cdot 70)$ \\
FEV after salbutamol (1) $_{\text {FVC (1) }}$ & $1 \cdot 19 \pm 0.49(0.15 \pm 0.67$ \\
$\begin{array}{l}\text { 12-minute walking } \\
\text { distance (m) }\end{array}$ & $2 \cdot 32 \pm 0 \cdot 77(0 \cdot 78-3 \cdot 50)$ & $2 \cdot 38 \pm 0 \cdot 94(1 \cdot 32-5 \cdot 00)$ \\
& $802 \pm 156(410-1020)$ & $769 \pm 156(470-996)$
\end{tabular}

\section{Results}

Seventeen patients were enrolled in the exercise group; two dropped out at an early stage and one died suddenly from a myocardial infarction after 10 months' follow-up. In the control group of 16 patients two died from respiratory failure and one from myocardial infarction. The total patient follow-up time was 162 months in the exercise group (mean 10.8 months) and 156 months in the control group (mean 10.4 months).

Both groups were well matched for age, ventilatory function, and 12-minute walking distance (table I). Apart from a significant improvement in the mean FVC in the exercise group (table II), ventilatory function, lung volumes, and diffusion were unchanged at the sixmonth and final assessments. Right quadriceps strength was reduced in the controls. There was no change in thigh circumference, body weight, minute ventilation, or heart rate in either group (table II).

There was a highly significant improvement in the mean 12-minute walking distance at six months and at the final assessment in the exercise group; all patients improved, the range being +108 metres to +341 metres $(12.3 \%$ to $83 \%)$ at the final assessment. The number of steps fell significantly, indicating an increase in the length of stride. There was no significant change in the control group (table III). More detailed analysis of the 12-minute distances (table IV) showed that the improvement was gradual, reaching a maximum between eight and 12 months.

Electrocardiographs showed no significant change over the period of follow-up. Chest radiographs showed emphysematous changes in 11 patients in each group.

Subjective changes are detailed in table V. The exercise group showed a significant improvement for each symptom compared with the controls $\left(\chi^{2}\right.$ test). Four patients from the exercise group were readmitted due to an exacerbation of their bronchitis, while in the controls there were 10 readmissions affecting seven patients.

\section{Discussion}

McGavin et al ${ }^{1}$ showed a mean improvement in the 12-minute walking distance of 64 metres $(6.3 \%)$ in a group of patients with chronic bronchitis who were asked to exercise daily at home without supervision over a mean of three months. In our study the mean increase attained after 8 months was 185 metres $(23.4 \%)$ and this was maintained for the rest of follow-up. This improvement occurred in patients whose condition was considered to be clinically optimal at the time of discharge from hospital. For greatest benefit training should be specific for the exercise assessed, ${ }^{6}$ and in this study training included a daily

TABLE II-Mean and predicted values for FEV,$F V C$, and body weight and quadriceps strength, minute ventilation, and heart rate ( \pm SD) at oxygen consumption of $33.5 \mathrm{mmol} / \mathrm{min}(0.75 \mathrm{l} / \mathrm{min})$, at initial, six-monih, and final assessments for exercise and control groups

\begin{tabular}{|c|c|c|c|c|c|c|c|}
\hline & \multirow[b]{2}{*}{ Predicted } & \multicolumn{3}{|c|}{ Exercise group } & \multicolumn{3}{|c|}{ Control group } \\
\hline & & $\begin{array}{c}\text { Initial } \\
(n=17)\end{array}$ & $\begin{array}{l}6 \text { month } \\
(\mathrm{n}=15)\end{array}$ & $\begin{array}{c}\text { Final } \\
(n=12)\end{array}$ & $\begin{array}{c}\text { Initial } \\
(n=16)\end{array}$ & $\begin{array}{l}6 \text { month } \\
(\mathrm{n}=14)\end{array}$ & $\begin{array}{c}\text { Final } \\
(\mathrm{n}=10)\end{array}$ \\
\hline $\begin{array}{l}\mathrm{FEV}_{1}(1) \\
\text { FVC (1) } \\
\text { Body weight (kg) } \\
\text { Quadriceps strength (kg) }\end{array}$ & $\begin{array}{l}2.65 \\
3.64\end{array}$ & $\begin{array}{l}1 \cdot 10 \\
2 \cdot 32 \\
66 \cdot 4\end{array}$ & $\begin{array}{l}1 \cdot 18 \\
2 \cdot 64^{*} \\
65 \cdot 3\end{array}$ & $\begin{array}{l}1 \cdot 11 \\
2.51 * \\
66.8\end{array}$ & $\begin{array}{l}1 \cdot 02 \\
2 \cdot 38 \\
59 \cdot 5\end{array}$ & $\begin{array}{l}1 \cdot 09 \\
2 \cdot 40 \\
62 \cdot 9\end{array}$ & $\begin{array}{l}0 \cdot 88 \\
2 \cdot 31 \\
60 \cdot 6\end{array}$ \\
\hline $\begin{array}{l}\text { Right } \\
\text { Left }\end{array}$ & & $\begin{array}{l}17 \cdot 6 \pm 4.9 \\
18 \cdot 3 \pm 4 \cdot 2\end{array}$ & $\begin{array}{l}17 \cdot 4 \pm 2 \cdot 7 \\
17 \cdot 2 \pm 3 \cdot 7\end{array}$ & $\begin{array}{l}16 \cdot 9 \pm 4 \cdot 7 \\
16 \cdot 8 \pm 4 \cdot 5\end{array}$ & $\begin{array}{l}i 8 \cdot 8 \pm 5 \cdot 8 \\
18 \cdot 4 \pm 6 \cdot 7\end{array}$ & $\begin{array}{l}17 \cdot 4 \pm 2 \cdot 6 \\
17 \cdot 5 \pm 3 \cdot 7\end{array}$ & $\begin{array}{l}16 \cdot 3 \pm 3 \cdot 0^{*} \\
17 \cdot 9 \pm 3 \cdot 5\end{array}$ \\
\hline $\begin{array}{l}\text { Minute ventilation }(1 / \mathrm{min}) \\
\text { Heart rate (beats } / \mathrm{min})\end{array}$ & & $\begin{array}{c}(\mathrm{n}=14) \\
20 \cdot 3 \pm 3 \cdot 8 \\
102 \cdot 5 \pm 16 \cdot 6\end{array}$ & $\begin{array}{c}21 \cdot 7 \pm 4 \cdot 1 \\
106 \cdot 4 \pm 15 \cdot 4\end{array}$ & $\begin{array}{c}(\mathrm{n}=10) \\
22 \cdot 9 \pm 2 \cdot 4 \\
108 \cdot 7 \pm 16 \cdot 1\end{array}$ & $\begin{array}{c}(\mathrm{n}=11) \\
19 \cdot 3 \pm 3 \cdot 2 \\
100 \cdot 0 \pm 18 \cdot 1\end{array}$ & $\begin{array}{c}(\mathrm{n}=8) \\
21 \cdot 4 \pm 2 \cdot 8 \\
112 \cdot 7 \pm 19 \cdot 6\end{array}$ & $\begin{aligned}(\mathrm{n}=6) & = \\
21 \cdot 1 & \pm 3 \cdot 3 \\
117 \cdot 8 & \pm 23 \cdot 0\end{aligned}$ \\
\hline
\end{tabular}

${ }^{*} \mathrm{p}<0.05$ compared with initial value.

TABLE III-Mean $( \pm S D)$ initial 12-minute walking distance and changes at six months and final assessments, number of steps per 100 metres, and mean increase in pulse rate after exercise for exercise and control groups

\begin{tabular}{|c|c|c|c|c|c|c|}
\hline & \multicolumn{3}{|c|}{ Exercise group } & \multicolumn{3}{|c|}{ Control group } \\
\hline & $\begin{array}{c}\text { Initial } \\
(\mathrm{n}=17)\end{array}$ & $\begin{array}{l}6 \text { month } \\
(\mathrm{n}=15)\end{array}$ & $\underset{(n=12)}{\text { Final }}$ & $\begin{array}{c}\text { Initial } \\
(n=16)\end{array}$ & $\begin{array}{l}6 \text { month } \\
(n=14)\end{array}$ & $\begin{array}{c}\text { Final } \\
(n=10)\end{array}$ \\
\hline $\begin{array}{l}\text { 12-minute walking distance }(\mathrm{m}) \\
\text { No of steps per } 100 \text { metres } \\
\text { Increase in pulse rate (beats } / \mathrm{min} \text { ) }\end{array}$ & $\begin{array}{r}802 \pm 156 \\
138 \cdot 8 \pm 18 \cdot 6 \\
+29 \cdot 9 \pm 15 \cdot 7\end{array}$ & $\begin{array}{l}+174 \pm 89 * * \\
129 \cdot 2 \pm 12 \cdot 9^{*} \\
+34 \cdot 8 \pm 15 \cdot 1^{*}\end{array}$ & $\begin{array}{l}+203 \pm 77^{* *} \\
129 \cdot 1 \pm 12 \cdot 0^{*} \\
+40 \cdot 6 \pm 13 \cdot 2^{*}\end{array}$ & $\begin{array}{r}769 \pm 156 \\
139 \cdot 6 \pm 13 \cdot 4 \\
+22 \cdot 1 \pm 17 \cdot 9\end{array}$ & $\begin{array}{r}-13 \pm 128 \\
136.5 \pm 16.8 \\
+19.9 \pm 15.9\end{array}$ & $\begin{array}{r}-19 \pm 114 \\
138 \cdot 1 \pm 15 \cdot 7 \\
+24 \cdot 0 \pm 14 \cdot 4\end{array}$ \\
\hline
\end{tabular}

${ }^{*} \mathrm{p}<0.01$ and ${ }^{* *} \mathrm{p}<0.001$ compared with initial value. 
TABLE IV--Mean $( \pm S D)$ initial 12-minute walking distance and changes at two-month intervals and percentage improvement over initial values for patients in the exercise group

\begin{tabular}{|c|c|c|c|c|c|c|c|}
\hline & \multicolumn{7}{|c|}{ Months } \\
\hline & $\begin{array}{c}\text { Initial } \\
(\mathrm{n}=17)\end{array}$ & $(\mathrm{n}=15)$ & $\begin{array}{c}4 \\
(n=14)\end{array}$ & $(\mathrm{n}=15)$ & $\begin{array}{c}8 \\
(n=12)\end{array}$ & $\begin{array}{c}10 \\
(n=10)\end{array}$ & $(\mathrm{n}=8)$ \\
\hline $\begin{array}{l}\text { 12-minute walking distance }(\mathrm{m}) \\
0 \% \text { Change over baseline for each group }\end{array}$ & $802 \pm 170$ & $\begin{array}{l}73 * \pm 90 \\
9 \cdot 1\end{array}$ & $\begin{array}{c}+145 * * \pm 95 \\
17 \cdot 6\end{array}$ & $\begin{array}{c}+174 * * \pm 90 \\
21 \cdot 6\end{array}$ & $\begin{array}{c}+185 * * \pm .82 \\
23 \cdot 4\end{array}$ & $\begin{array}{c}+195 * * \pm 81 \\
23 \cdot 6\end{array}$ & $+\underset{24 \cdot 2}{203 * * \pm 73}$ \\
\hline
\end{tabular}

${ }^{*} \mathrm{p}<0.01^{\prime}$ and ${ }^{* *} \mathrm{p}<0.001$ when compared with initial value.

TABLE V-Subjective changes between initial and final assessments in exercise and control groups

\begin{tabular}{|c|c|c|c|c|c|c|c|}
\hline & \multicolumn{3}{|c|}{ Exercise group } & \multicolumn{3}{|c|}{ Control group } & \multirow[b]{2}{*}{$\mathrm{p}$ Value } \\
\hline & Deterioration & $\begin{array}{c}\text { No } \\
\text { change }\end{array}$ & Improvement & Deterioration & $\begin{array}{c}\text { No } \\
\text { change }\end{array}$ & Improvement & \\
\hline $\begin{array}{l}\text { Dyspnoea } \\
\text { General wellbeing } \\
\text { Daily activity }\end{array}$ & $\begin{array}{l}0 \\
0 \\
0\end{array}$ & $\begin{array}{l}0 \\
3 \\
5\end{array}$ & $\begin{array}{l}15 \\
12 \\
10\end{array}$ & $\begin{array}{l}8 \\
7 \\
7\end{array}$ & $\begin{array}{l}2 \\
3 \\
3\end{array}$ & $\begin{array}{l}5 \\
5 \\
5\end{array}$ & $\begin{array}{l}<0.02 \\
<0.02 \\
<0.02\end{array}$ \\
\hline
\end{tabular}

TABLE VI-Percentage change in 12-minute walking distance between initial and final assessments in smokers and non-smokers in the exercise and control groups

\begin{tabular}{lcclll}
\hline & \multicolumn{2}{c}{ Exercise group } & & \multicolumn{2}{c}{ Control group } \\
\cline { 2 - 3 } \cline { 5 - 6 } & $\begin{array}{c}\text { Non-smokers } \\
(\mathrm{n}=12)\end{array}$ & $\begin{array}{c}\text { Smokers } \\
(\mathrm{n}=3)\end{array}$ & $\begin{array}{c}\text { Non-smokers } \\
(\mathrm{n}=7)\end{array}$ & $\begin{array}{c}\text { Smokers } \\
(\mathrm{n}=8)\end{array}$ \\
\hline $\begin{array}{c}\text { o. Change in 12-minute } \\
\text { walking distance: }\end{array}$ & +26 & +16 & & +1.6 & -11 \\
\hline
\end{tabular}

walk of at least 12 minutes. Supervision was particularly important during the early stages, when improvement was slow. These factors-close supervision, exercise-specific training, and longer duration of follow-up-may well account for the greater improvement than previously reported.

No consistent pattern of physiological changes has been reported in response to exercise training in chronic bronchitis.? Since there was no significant change in ventilation or heart rate during exercise this does not appear to be a major factor in the improved exercise capacity. The increase in FVC in the exercise group may reflect reduction in air trapping and has been noted previously. ${ }^{8}{ }^{9}$ Improved exercise capacity may be related to improved neuromuscular co-ordination ${ }^{1910}$ and increased muscle endurance. ${ }^{8}$ Length of stride in the exercise group increased, indicating a more efficient stride pattern, ${ }^{6}$ but muscle strength was not improved.

Long-term follow-up of patients with chronic obstructive lung disease who have performed regular physical exercise has shown continued improvement even up to two years. ${ }^{8}{ }^{9}$ In our patients improvement was gradual, reaching a maximum at eight months, which suggests that any training regimen should be continued for at least six to 12 months. More patients in the exercise group gave up smoking than in the control group, but analysis of the 12-minute distance results according to smoking habit (using a two-sample $t$ test) showed no statistical differences (table VI); cessation of smoking was therefore not a major factor in the overall improvement in the exercise group. As antibiotics were not prescribed during follow-up the reduced hospital readmission rates in the exercise group cannot be attributed to the earlier treatment of infection and would seem to be a benefit of improved general condition and fitness attributable to the exercise programme. No special skills are required to supervise such a programme and in some cases training at home was supervised by a member of the patient's family. This would seem to be the ideal situation for the long term.

This controlled trial clearly reaffirms reports that much benefit can be obtained by daily physical exercise in patients with severe airways obstruction and emphysema. Increase in exercise capacity and wellbeing is considerable and the ability to carry out daily tasks greatly improved. These improvements are not dependent on specified changes in pulmonary or cardiac function, or muscle power and probably depend on the patients' better tolerance of dyspnoea and adaptation to their physical incapacity. With motivation and perseverance surprising improvement can be expected even in the severely disabled.

We thank the Chest, Heart, and Stroke Association for funding the research nurse; staff nurse $M$ Nicoll for her dedication and enthusiasm; Dr R N Johnston for helpful advice; Dr R A Clark for allowing us to study patients under his care; Mrs P Reid for technical help; and Mr S Ogston for statistical advice.

\section{References}

${ }^{1}$ McGavin CR, Gupta SP, Lloyd EL, McHardy GJR. Physical rehabilitation for the chronic bronchitic: results of a controlled trial of exercises in the home. Thorax 1977;32:307-11.

${ }^{2}$ Medical Research Council. Definition and classification of chronic bronchitis. Lancet $1965 ; \mathrm{i}: 775-9$.

${ }^{3}$ McGavin CR, Gupta SP, McHardy GJR. Twelve-minute walking test for assessing disability in chronic bronchitis. $\mathrm{Br} \mathrm{Med} \mathrm{F} \mathrm{1976;i:822-3.}$

${ }^{4}$ Mungall IPF, Hainsworth R. Assessment of respiratory function in patients with chronic obstructive airways disease. Thorax 1979;34: 254-8.

${ }^{5}$ Edwards RHT, Young A, Hosking. GP, Jones DA. Human skeletal muscle function: description of tests and normal values. Clin Sci Mol Med 1977;52:283-90.

${ }^{6}$ Paez PN, Phillipson EA, Masangkay M, Sproule BJ. The physiological basis of training patients with emphysema. Am Rev Respir Dis 1967; 95 : $944-53$.

7 Shephard RJ. Exercise and chronic obstructive lung disease. Exerc Sport Sci Rev 1976;4:263-96.

${ }^{8}$ Mertens DJ, Shephard RJ, Kavanagh T. Long-term exercise therapy for chronic obstructive lung disease. Respiration 1978;35:96-107.

${ }^{9}$ Brundin A. Physical training in severe chronic obstructive lung disease. Scand $\mathcal{F}$ Respir Dis $1974 ; 55: 25-36$.

10 Pierce AK, Taylor HF, Archer RK, Miller WF. Responses to exercise training in patients with emphysema. Arch Intern Med 1964;113:28-36.

(Accepted 27 November 1979)

ONE HUNDRED YEARS AGO The London Hospital has, we are informed, received a splendid Christmas-box in the shape of an anonymous contribution of $£ 5,000$ to the funds of that charity. The enclosure was left by a lady at the porter's gate in an envelope, addressed to the secretary, and without any further information (British Medical fournal, 1880.) 